Gunnar Schrøder Kri- Paul Hirst og Grahame stiansen, Thompson,

Mellom natur og kultur. Essays. Globalisering til debat. Om den C. Huitfeldt Forlag, Oslo 2000. internationale økonomi og mulig354 sider, 248 (norske) kr.

Gunnar Schrøder Kristiansen,

Jens Kraft og opplysningen Filosofi og vitenskap i Danmark-Norge i det 18. århundre. Spartacus, Oslo 2001.163 sider, 195 (norske) kr.

Den unge norske idéhistoriker Gunnar Schrøder Kristiansen har skrevet to meget forskellige bøger: en essaysamling med aktualiserende perspektiv om forholdet mellem natur og kultur, og en mere traditionel idé- og videnskabshistorisk bog om den dansk-norske filosof og videnskabsmand Jens Kraft. Kristiansen demonstrerer med sine to på hver deres måde oplysende og velskrevne bøger gode evner for både den historisk orienterede og den aktualiserende idéhistorie. Mellom natur og kultur er bredt anlagt og trækker på den intellektuelle histories kanoniserede mestre såvel som på populærkulturen. Jens Kraft og opplysningen er et fint bidrag til dansk-norsk naturvidenskabs- og filosofihistorie.

Peter C. Kjargaard hederne for governance, oversat fra engelsk af Morten F. Greve, Hans Reitzels Forlag, København 2001, 400 sider, $350 \mathrm{kr}$.

I 1996 udgav Paul Hirst og Grahame Thompson bogen Globalization in Question. The International Economy and the Possibilities of Governance. Denne bog adskilte sig fra den strøm af bøger om globalisering, der fra begyndelsen af halvfemserne havde oversvømmet markedet, ved at være stærkt kritisk overfor ideen om, at vi nu levede i en verden, der var mere globaliseret end nogensinde før, og i en verden der var totalt domineret af de multinationale virksomheder. Via empiriske data forsøgte Hirst og Thomson at undersøge, hvor nyt et fænomen, der egentlig var tale om. Samtidigt diskuterede de nationalstaternes fortsatte muligheder for at føre politik. Udgivelsen af bogen førte til debat verden over, og Globalization in Question. The International Economy and the Possibilities of Governance blev - måske ikke overraskende angrebet fra forskelligt hold. Debatten og indvendingerne samt ikke mindst den økonomiske krise i Asien fra 1997 og frem blev anledning til at udgive en revideret og opdateret udgave af bogen i 1999. Det er denne anden, reviderede udgave, der ligger til grund for den danske oversættelse.

Mads P. Sorensen 


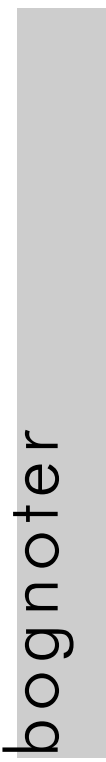

\section{Claus Bryld,}

Kampen om historien - brug og misbrug af historien siden murens fald, Roskilde Universitetsforlag, Roskilde 2001, 237 sider, 198 kr.

Claus Bryld har samlet en række af sine indlæg $\mathrm{i}$ historiedebatten og tilføjet enkelte nye $i$ denne bog om fortolkningskampene efter den nyere histories væsentligste begivenheder, 2 . Verdenskrig, '68 og Murens fald. Der er tale om engagerede og velfunderede opgør med politiserende forenklinger, der vil reducere historien til et spørgsmål om valg mellem godt og ondt $i$ fortiden. Dertil kommer nogle almene diskussioner af historiens rolle $\mathrm{i}$ dagens samfund, der sætter fokus på forholdet mellem historie, identitet og erindring. En række både historisk og idéhistorisk interessante spørgsmål kommer i spil i disse tekster fra bogens anden halvdel: Er historien slut med Murens fald, som Francis Fukuyama hævdede? Erhistorien blevet et instrument til reklame eller individuel iscenesættelse? Er det umuligt at forbinde historien og den kollektive erindring? Claus Bryld presenterer sine svar som foreløbige og prøvende, og giver således udtryk for en åbenhed over for fortolkningsprocessen, som korresponderer med påpegningen af, at slagsmål om den kollektive erindring er at foretrække frem for "en opløsning af historiebevidsthed(en) $\mathrm{i}$ individernes selvspejling med lejlighedsvis fejring af samfundets store fortidsstunder i karnevalistisk iscenesættelse".

Henrik Borup Nielsen
Theresa Schilhab,

Den bio-logiske bevidsthed - En historie om bevidsthedens natur, Forlaget Fremad, København 2000, 217 sider, 268 kr.

Inden for de seneste årtier er begrebet og fænomenet bevidsthed i stigende grad blevet gjort til genstand for forskellige former for teoretisk og praktisk opmærksomhed. Hvor bevidstheden før har figureret som først filosofiens og senere psykologiens domæne er det afgørende ved den nyvakte interesse for bevidstheden, at den ikke længere er lokaliseret $i$ en snæver kreds af humanistiske videnskaber. I stedet er den i væsentlig grad betinget af bevidsthedens fødsel som videnskabeligt forskningsfelt inden for det, der med bred betegnelse kan udpeges som natur- og sundhedsvidenskaberne. Særligt interessant er fremkomsten af den såkaldte kognitionsforskning, der som et tværvidenskabeligt forskningsprogram forsøger at afdække bevidsthedsfænomener ved hjælp af metoder og begreber hentet fra forskellige vidensformer.

Neurobiologen og filosoffen Theresa Schilhab indskriver sig med bogen Den bio-logiske bevidsthed i denne fornyede interesse for bevidstheden. Med afsæt $i$ en fremstilling af bevidsthedsbegrebets idéhistorie og mangfoldige videnskabelige og filosofiske udlægninger, fremstiller Shilhab en evolutionsbaseret bevidsthedsvidenskab. Uden at havne i en reduktiv biologisme forsøger forfatteren således at godtgøre at dele af den organiske 
natur har udviklet egenskaber og processer, der er bevidste.

Anders Draby Sorensen

\section{Randall Collins,}

Max Weber - personen og forfatterskabet, Hans Reitzels Forlag, København 2000, 184 sider, 198 kr.

Randall Collins' bog Max Weber - personen og forfatterskabet er en oversættelse af bogen Max Weber. A Skeleton Key fra 1986. I bogens første kapitel gennemgår Collins Max Webers (1864-1920) alt andet end almindelige liv, og han forsøger at give læseren et indblik $\mathrm{i}$ Webers komplicerede og sammensatte personlighed. Bogen er dog - heldigvis - først og fremmest en introduktion til nogle af grundtankerne $i$ Webers sociologi. Vi præsenteres således i den resterende del af bogen for grundteorierne i Webers omfattende forfatterskab. Således gennemgår Collins fx Webers teorier om 'den protestantiske etik og kapitalismens ånd' og om rationalisering.

Mads P. Sorensen
Benny Karpatschof, Human Activity. Contributions to the Anthropological Sciences from a Perspective of Activity Theory, Dansk Psykologisk Forlag, København 2000, 528 sider, $350 \mathrm{kr}$.

Lektori videnskabsteori og metodelære ved Psykologisk Institut på Københavns Universitet, Benny Karpatschof, har fået sin disputats fra 1997 omfattende den såkaldte virksomhedsteori (Activity Theory) udgivet på Dansk Psykologisk Forlag.

Bogen indledes med en fremstilling af virksomhedsteoriens historiske baggrund, der strækker sig fra udviklingen af teorien hos Hegel og Marx til de to russiske psykologer Vygotsky og Leontiev fra den kulturhistoriske skole. Virksomhedsteorien fremstilles derefter som et forsøg på at forene et evolutionsteoretisk og et kulturhistorisk syn på mennesket, og der argumenteres for et begreb om den menneskelige virksomhed som fundament for bl.a. psykologi og samfundsvidenskab. Bogens hovedsigte kan nemlig først og fremmest sammenfattes som den videnskabsteoretiske hypotese om, at virksomhedsteorien er nøglen til at løse grundlagsproblemer i - først og fremmest - en række af humanvidenskaberne.

Anders Draby Sorensen 
Søren Lind,

Bevidstheden, Modtryk, Århus 2001, 45 sider, 59 kr.

Morten Ebbe Juul Nielsen,

Etik, Modtryk, Århus 2001, 47 sider, $59 \mathrm{kr}$.

"Hellere lidt men godt end meget og alligevel ingenting" er vel et udtryk, det er de fleste mennesker beskåret at kunne forstå, og som de, der i et eller andet omfang er tynget af tankens himmelflugt, kan billige. Det er også baggrunden for forlaget Modtryks nystartede filosofiserie KORT OG GODT. Serien er tænkt som en række små introduktioner til store emner, der $i$ et tilgængeligt sprog skal bevæge til dybere eftertanke og videre debat. I bogen Bevidstheden tilsigter Søren Lind en indkredsning af forholdet mellem sjæl og legeme, således som det manifesterer sig i spørgsmålet om, hvad bevidsthed er for en størrelse. Spørgsmålet sættes via forskellige tekstnedslag ind i såvel en historisk som en aktuel sammenhæng. I bogen Etik rejser Morten Ebbe Juul Nielsen spørgsmålet om, hvad etik egentlig er, og der præsenteres en række centrale positioner indenfor den etiske teori med særligt henblik på den såkaldt normative etik, der ikke blot slår sig til tåls med fænomenologisk at sige noget om, hvordan tingene er, men tværtimod drister sig til at udsige, hvordan tingene bør være. For begge udgivelsers vedkommende gælder det, at de er forsynet med forslag til videre læsning.
Einar Aadland,

Etik - dilemma og valg, Dansk Psykologisk Forlag, København 2000, 336 sider, 295 kr.

Einar Aadland er førsteamanuensis ved Diakonhjemmets Høgskolesenter i Oslo og har skrevet en indføring $\mathrm{i}$ etik, der er blevet oversat til dansk og udgivet på Dansk Psykologisk Forlag. At netop dette forlag har valgt at udgive Aadlands bog er ingen tilfældighed, da den overvejende henvender sig til professionelle inden for de arbejdsområder, der har mennesker på programmet.

På denne baggrund bliver bogens omdrejningspunkt forholdet mellem teori og praktisk arbejde, som den over tre hoveddele forsøger at trække en række linier igennem: I bogens første og længste del fremstilles det teoretiske grundlag for etikken med baggrund i en omhyggelig indføring $i$ de mest centrale etiske positioner (dydsetik, omsorgsetik, pligtetik, diskursetik og konsekvensetik). I bogens anden del anvendes det teoretiske grundlag under overskriften den faglige etik derefter som fundament for fremstillingen af en praktisk anvendelig model for den etiske refleksion. Endelig er bogens tredje, sidste og korteste del et mestendels praktisk afsnit, der over syv casestories behandler det etiske dilemma og valg i forskellige konkrete situationer.

Anders Draby Sorensen 